concentration against PT and PRN differed significantly between the genotypes after the original vaccination, at 3-year follow-up and before the second booster.

Conclusion These preliminary results suggest that IL-10 might play an important role in modulating both antibody and cell mediated immune responses after pertussis vaccination.

\section{PO-0187 VALUE OF SERUM PROCALCITONIN LEVEL IN DIFFERENTIATION OF VIRAL AND BACTERIAL MENINGITIS IN CHILDREN ADMITTED EMERGENCY ROOM}

A Hamedi. Pediatrics, Mashhad University of Medical Sciences, Mashhad, Iran

\subsection{6/archdischild-2014-307384.848}

Introduction Acute bacterial meningitis which is a paediatric emergency with high mortality and morbidity, must be diagnosed and treat promptly. Often diagnosis of bacterial meningitis from viral meningitis is difficult after some days. Determination of some inflammatory mediators example procalcitonin in serum and CSF were useful in differential diagnosis of bacterial and viral meningitis. The aim of this study is the finding out value for procalcitonin in meningitis.

Methods This research is a case control cross sectional study in all children with clinically suspected meningitis referred to paediatric emergency room. According to the clinical finding and results of CSF analysis, our patients were classified into two groups: bacterial meningitis and aseptic meningitis. For all cases CSF analysis and Culture was done and serum and CSF procalcitonin measured,. Finally the results Compared Groups. Data were analysed by SPSS Software.

Results There is no significant difference between two groups, in age, Sex, and symptoms. Serum and CSF procalcitonin, Leukocytosis $>15000$, PMN peleocytosis of CSF and also sugarand protein of CSF were significantly higher in bacterial meningitis. Serum and CSF procalcitonin levels in control group were less than $0.5 \mathrm{ng} / \mathrm{ml}$ and $>2 \mathrm{ng} / \mathrm{ml}$ in bacterial meningitis and only one child $(8.33 \%)$ in aseptic meningitis (Herpes meningoencephalitis) had serum procalcitonin more than $2 \mathrm{ng} / \mathrm{ml}$ same bacterial meningitis.

Conclusion Serum and CSF Procalcitonin level Could be used as a useful diagnostic in meningitis with the cut of point $0.5 \mathrm{ng} / \mathrm{ml}$ and in bacterial meningitis with $>2 \mathrm{ng} / \mathrm{ml}$.

\section{P0-0188 WITHDRAWN}

\section{P0-0189 FIVE YEAR STUDY ON EPIDEMIOLOGY, CLINICAL CHARACTERISTICS AND RISK FACTORS OF INVASIVE NON-TYPHOIDAL SALMONELLOSIS IN SINGAPORE}

$\underline{V}$ Ho, H Lim, SS Krishnamoorthy, KC Thoon. Paediatric Medicine, KK Women's and Children's Hospital, Singapore, Singapore

10.1136/archdischild-2014-307384.849

Introduction Non-typhoidal salmonellosis (NTS) can cause invasive disease in special groups of children. Increasing antimicrobial resistance and limited epidemiological data pose major limitations to therapy. This study aims to analyse the disease characteristics in Singapore children.
Methods Retrospective cross- sectional study of children aged 0-16 years with invasive NTS over a 5 -year period (January 2006-December 2011). Invasive NTS disease was defined as NTS species identified from normally sterile extra-intestinal sites ie. Blood and cerebrospinal fluid cultures.

Results There were 51 cases of which 22(43\%) were female and $29(57 \%)$ were male. The median age at presentation was 15 months. $45(88.2 \%)$ patients were under 4 years and the youngest was 13 days old.

Fever and/or diarrhoea were most common presenting complaints. All had temperature $>38^{\circ} \mathrm{C}$ and 40 (78.4\%) had diarrhoea with 19(47.5\%) having bloody stools.

Mean initial total white cell count and C-reactive protein were $12.8 \times 10^{\wedge} 9 / \mathrm{L}$ and $64.2 \mathrm{mg} / \mathrm{L}$ respectively with Group D and B Salmonella species as the major isolates in $21(41.2 \%)$ and 17(33.3\%). Group C accounted for 7(13.7\%) while Group G / other non-typable ones contributed $6(11.8 \%)$. Meningitis was confirmed in 3(5.9\%). One child (1.9\%) died of drug-related fulminant liver failure and there were no readmissions. Antibiotic resistance was noted in 16 (31.3\%).

Conclusion There should be a high index of suspicion for NTS bacteremia in younger age group ( $\leq 4$ years old) who present with fever and bloody diarrhoea. Initial inflammatory markers are not indicators of severity. Antimicrobial resistance in NTS in Singapore is low but needs vigilance.

\section{PO-0190 WITHDRAWN}

\section{P0-0191 VARICELLA COMPLICATIONS - COULD WE DO MORE?}

R Komitova, I Boev, Z Kazakova, M Bojilova, O Bojkinova. Infectious Diseases, University Hospital "St. George", Plovdiv, Bulgaria

\subsection{6/archdischild-2014-307384.850}

Background and aims The purpose of this study was to retrospectively evaluate the severe chickenpox complications among immunocompetent children.

Methods During a 5-year period medical records of children aged.

Results We reviewed 269 cases with varicella admitted to Plovdiv University Hospital, Infectious Diseases Clinic from January 2009 to December 2013. One hundred ninety four were excluded as the reason for admission was dehydration. Another 53 patients, hospitalised due to epidemiological considerations were also excluded. Finally, 22 cases met the definition of severe complications - 12 girls, 10 boys (mean age 4,12). The most common complications were respiratory tract infections (17 cases), followed by thrombocytopenic purpura in 2 and cerebellar ataxia, sepsis and scarlet fever a single case of each one. Patients were admitted 4,8 days post the onset of varicella. The mean duration of hospitalisation was 5,7 days. Antibiotics were administrated in all patients, in 11 acyclovir was also added. All recovered completely without any sequels.

Conclusion Severe complications were rare with respiratory tract infections being the most frequent. Haematological complications, although potentially life-threatening, were uncommon.

Our results indicate that further studies are needed for assessing the burden of varicella, and estimating cost effectiveness of varicella vaccine. 